Editorial

\title{
Policy Debates and Discourse Network Analysis: A Research Agenda
}

\author{
Philip Leifeld \\ Department of Government, University of Essex, Colchester, CO4 6BW, UK; E-Mail: philip.leifeld@essex.ac.uk
}

Submitted: 15 May 2020 | Published: 2 June 2020

\begin{abstract}
Discourse network analysis (DNA) is a combination of network analysis and qualitative content analysis. DNA has been applied to various policy processes and debates to show how policy actors are related at the discursive level, complementing coordination relations among them that are often analysed in the application of the policy networks approach. This editorial takes stock of the theoretical and methodological research frontiers in DNA and summarises the contributions of the eleven articles in the thematic issue on "Policy Debates and Discourse Network Analysis" in Politics and Governance.
\end{abstract}

\section{Keywords}

content analysis; discourse network analysis; policy debate; policy process; public policy; social network analysis

\section{Issue}

This editorial is part of the issue "Policy Debates and Discourse Network Analysis" edited by Philip Leifeld (University of Essex, UK).

(C) 2020 by the author; licensee Cogitatio (Lisbon, Portugal). This article is licensed under a Creative Commons Attribution 4.0 International License (CC BY).

\section{Introduction}

In the study of policy processes, many theories and frameworks (Weible \& Sabatier, 2017) revolve around a number of common themes: political actors (such as interest groups, government agencies, legislators, and scientific actors); coalitions in which these actors organise in order to influence policy making; the networks through which they engage with, and perceive, each other; the issues, topics, policy sectors, problems, or policy domains they are concerned with; actors' beliefs and interpretations and resulting belief systems, discourses, and narratives with regard to policy problems; the timing of decisions and opportunities; actors' resources and their resulting power and reputation; as well as institutions, broadly understood as the set of rules of the system, and their constraining or enabling forces. Policy process theories or frameworks usually combine some of these elements to explain why, how, and when policy change happens.

A strong empirical tradition in this field is the study of policy networks, which focuses on the information flows, collaboration, and exchange of resources among political actors in order to explain who gets to influence policy outcomes in any given policy domain or subsystem (Kenis \& Schneider, 1991; Leifeld \& Schneider, 2012). In the last ten years, this focus on the material, actual coordination networks among actors was merged with ideational approaches, such as the advocacy coalition framework (Ingold, 2011; Sabatier \& Jenkins-Smith, 1993), which focus more on actors' beliefs, belief systems, policy learning, and resulting coalitions-rather intangible relationships between actors. Despite an early focus of these approaches on policy beliefs, the tools of policy network analysis were increasingly borrowed to replace the study of belief systems in advocacy coalitions by the study of coordination (e.g., Ingold, 2011; Schlager, 1995). Enter discourse network analysis (DNA). DNA is an attempt at measuring actors' policy beliefs and discourses systematically using text sources and moulding them into a data format that is compatible with policy network analysis. This endeavour serves to facilitate the joint analysis of material policy networks (the 'coordination layer') and ideational networks among the same actors (the 'discursive layer' or belief layer of subsystem politics).

Much of the methodological work on DNA has produced ways to achieve this fusion: Leifeld $(2016,2017)$ summarises the construction of affiliation networks, actor congruence networks, concept congruence networks, conflict networks, and normalisation methods for an effective analysis of discourse networks. These methods were implemented in the software Discourse Network 
Analyzer, a qualitative content analysis package that permits a nested, actor-based annotation of actors' usage of 'concepts' (broadly understood as the contents they talk about, including policy preferences or arguments) and export of the resulting network data to statistical software and network analysis packages. While the resulting networks can be analysed at the actor level, concept level, or a combined two-mode level, possibly over time, the most interesting level from a policy networks perspective is the actor level: An actor congruence network connects any two policy actors if they both use the same concept-possibly in different situations or source documents-in the same way at least once. More specifically, two actors both need to co-support the same concept or co-reject the same concept for them to be connected. The more concepts any two actors agree on (positively or negatively), the larger the tie weight becomes that connects the two actors, normalised by the average number of concepts the two actors use overall. This kind of network effectively mirrors the coordination relations found in the study of policy networks: Both kinds of networks are based on actors in a policy domain, and both kinds of networks can exhibit coalitions of actors as densely interconnected parts of the network.

\section{An Emerging Research Agenda}

The availability and compatibility of coordination networks and discourse networks bears interesting questions: How do the coalitions found in a coordination network differ from the coalitions found in a discourse network? How do the two kinds of relations influence each other? Can we simply employ DNA as a cheap-to-collect proxy measure for actual coordination? Policy networks are typically measured through interviews or surveys of elite actors, usually making repeated collection of such data prohibitively expensive. Discourse network data still require a big manual annotation effort, but changes over time can be recorded more effectively, to the extent that it becomes possible to trace the emergence and erosion of coalitions before important reforms happen (Leifeld, 2013; Leifeld \& Haunss, 2012). Are coordination relationships stable over time while discourse networks are volatile or cyclical? How do discourse networks vary across different arenas, policy domains, and types of source documents? Do actors spontaneously and independently exhibit discursive similarities in a debate, or do they influence each other directly (through the sources being analysed) or indirectly (by means of influencing public opinion, which in turn changes other actors' beliefs)? Does a segregation of actors into clusters, or coalitions, imply that the coalitions are in conflict with each other ('polarisation') or merely that they talk past each other and follow different policy paradigms, without antagonism ('segregation')? Are discourse networks different in consociational and majoritarian political systems? More generally, how do institutions shape the structure and development of discourse networks? With the availability of DNA, a vast research agenda in public policy is opened up to systematic inquiry. Empirical applications in different contexts will increasingly facilitate theoretical insights and guided comparison.

Meanwhile, DNA has been exported to adjacent problems and subfields, where the methodological toolbox proves useful for analysing ideational actor configurations more generally. In this thematic issue, for example, the contribution by Bhattacharya (2020) examines party unity among legislators using DNA; Abzianidze (2020) explores nationalist post-Soviet discourse and discursive coalitions in Georgia; and Rinscheid (2020) combines DNA with the analysis of public opinion using survey data. DNA not only proves useful for studying policy processes and debates in a positivist or realist paradigm, but increasingly attracts scholars who are interested in more traditional forms of discourse analysis (think Foucault or critical theory) and would like to add a systematic dimension to their analyses, in which they seek to uncover the power structures in society or politics through analyses of who says what. The analysis of higher education reform options in Germany by Nägler (2019) is a commendable example that seeks to describe discursive relations in a given field in an idiographic way, rather than seeking generalisation and inferring systematic cause-and-effect relationships across different contexts in a nomothetic research design (see also Leifeld, 2019 , on this point). The entry barriers seem low because learning basic exploratory network analysis does not require any understanding of econometrics.

Yet, discourse networks can also be analysed from a generative perspective, not just in a descriptive, exploratory, or macro-comparative way. Few scholars have embarked on this journey so far. The first point of departure is the agent-based computational model of the emergence of polarised coalitions in discourse networks presented in Leifeld (2014), followed by an application of a relational event model-an inferential statistical model for event-based temporal network data-to discourse networks by Leifeld and Brandenberger (2019) and Brandenberger (2019). The goal of this research is to identify the micro-level mechanisms by which actors contribute concepts to the debate, for example by learning from actors who exhibited prior similar concept usage, the drive for self-consistency, and other generative mechanisms that may lead to discourse network structures resembling those measured in empirical studies (e.g., Leifeld, 2013, 2016; Leifeld \& Haunss, 2012). Identifying the generative mechanisms behind policy debates as dynamic networks will be key to prediction and systematic comparison of discourse networks.

In addition to theoretical puzzles, several methodological research fronts will need to be addressed to permit better theory-led research. Among them are the identification of opinion leaders and other central positions in discourse networks by taking into account whose concepts diffuse the most; the measurement of polarisation between competing coalitions and how it changes 
over time; the systematic analysis of self-contradictions by actors and actors' loyalty to concepts; the scaling of actors' ideological positions as well as concepts on one or two dimensions for better comparison; the development of better generative models for discourse networks; (semi-)automatic annotation in lieu of manual annotation of actors' concepts; the development of intercoder reliability measures for DNA; and the sparsification of, or identification of significant ties in, discourse networks, to name just a few promising examples of how DNA research could be improved significantly.

\section{Contributions in This Thematic Issue}

The articles in this thematic issue contribute to the goals outlined in this overview of the discourse network research agenda-methodologically, theoretically, or by means of comparison. The first article by Schaub and Metz (2020) compares policy networks with discourse networks using a case study of micropollutants in water bodies. They find that both approaches reach similar coalition structures but have subtle differences in terms of actor composition. Kukkonen and Ylä-Anttila (2020) employ DNA in the second article to analyse the sciencepolicy interface in Finnish climate politics: an application of the DNA lens to a theoretical problem centred around a specific group of actors-scientists-and their connections to policy. Ghinoi and Steiner (2020) apply DNA to another specific group of actors-legislators from different parties-in their analysis of the climate debate in the Italian parliament. In the fourth article of this thematic issue, Bhattacharya (2020) introduces DNA to the comparative study of legislative politics by measuring party unity and party control in the German parliament with DNA, in a case study of the German response to the Euro crisis and the Greek bailout. This is a promising avenue for future research as we ultimately want to understand if and how discourse networks influence legislative behaviour and decisions. Abzianidze (2020) applies DNA to nationalist discourse and ethnic conflicts during Georgia's post-Soviet democratisation process, making use of the rich toolbox of social network analysis by applying structural equivalence, multidimensional scaling, and hierarchical cluster analysis. This extends the use of DNA to a new application domain. In the sixth article of this thematic issue, Wallaschek, Starke, and Brüning (2020) map and contrast the discourse networks around different types of solidarity in the public sphere in Germany. Černý and Ocelík (2020) apply DNA to uncover polarised advocacy coalitions in the debate on energy supply and the phasing out of coal in the Czech Republic. Rinscheid (2020) analyses energy policy in the Swiss context and focuses specifically on how incumbent business interest groups can appeal to voters. He combines DNA with public opinion surveys, which is an important avenue for learning more about the channels through which actors ultimately seek to influence policy making. In the ninth article, Howe, Stoddart, and Tindall
(2020) show how more media coverage of an actor is associated with higher perceived influence in the policy network, but not for individual activists. The authors thus link the discursive and policy network levels using regression models. Bossner and Nagel (2020) analyse Twitter messages during BBC 'Question Time' on 2 June 2017the final media encounter of Prime Minister Theresa May and her Labour Party contender in the context of the 2017 UK election campaign. They apply DNA primarily to the content categories of the debate and how groups of actors were related to types of content, which is a departure from actor-centred applications of DNA found elsewhere. The 11th and final article of this thematic issue by Haunss et al. (2020) makes a methodological contribution by comparing the speed and reliability of manual annotation of actors' statements and semi-automatic annotation supported by machine learning. They find that an integration of manual and computer-supported annotation may not speed up annotation significantly, but may be able to reproduce the core of a discourse network with high reliability. Overall, the contributions in this thematic issue demonstrate the breadth of applications and methodological developments pertaining to discourse networks and the analysis of policy debates using DNA.

\section{Conflict of Interests}

The author declares no conflict of interests.

\section{References}

Abzianidze, N. (2020). Us vs. them as structural equivalence: Analysing nationalist discourse networks in the Georgian print media. Politics and Governance, $8(2), 243-256$.

Bhattacharya, C. (2020). Gatekeeping the plenary floor: Discourse network analysis as a novel approach to party control. Politics and Governance, 8(2), 229-242.

Bossner, F., \& Nagel, M. (2020). Discourse networks and dual screening: Analyzing roles, content and motivations in political Twitter conversations. Politics and Governance, 8(2), 311-325.

Brandenberger, L. (2019). Predicting network events to assess goodness of fit of relational event models. Political Analysis, 27(4), 556-571.

Černý, O., \& Ocelík, P. (2020). Incumbents' strategies in media coverage: A case of the Czech coal policy. Politics and Governance, 8(2), 272-285.

Ghinoi, S., \& Steiner, B. (2020). The political debate on climate change in Italy: A discourse network analysis. Politics and Governance, 8(2), 215-228.

Haunss, S., Kuhn, J., Padó, S., Blessing, A., Blokker, N., Dayanik, E., \& Lapesa, G. (2020). Integrating manual and automatic annotation for the creation of discourse network data sets. Politics and Governance, 8(2), 326-339. 
Howe, A. C., Stoddart, M. C. J., \& Tindall, D. B. (2020). Media coverage and perceived policy influence of environmental actors: Good strategy or pyrrhic victory? Politics and Governance, 8(2), 298-310.

Ingold, K. (2011). Network structures within policy processes: Coalitions, power, and brokerage in Swiss climate policy. Policy Studies Journal, 39(3), 435-459.

Kenis, P., \& Schneider, V. (1991). Policy networks and policy analysis: Scrutinizing a new analytical toolbox. In B. Marin \& R. Mayntz (Eds.), Policy networks: Empirical evidence and theoretical considerations (pp. 2559). Frankfurt: Campus Verlag.

Kukkonen, A., \& Ylä-Anttila, T. (2020). The science-policy interface as a discourse network: Finland's climate change policy 2002-2015. Politics and Governance, 8(2), 200-214.

Leifeld, P. (2013). Reconceptualizing major policy change in the advocacy coalition framework: A discourse network analysis of German pension politics. Policy Studies Journal, 41(1), 169-198.

Leifeld, P. (2014). Polarization of coalitions in an agentbased model of political discourse. Computational Social Networks, 1(1), 7.

Leifeld, P. (2016). Policy debates as dynamic networks: German pension politics and privatization discourse. Frankfurt and New York, NY: Campus Verlag.

Leifeld, P. (2017). Discourse network analysis: Policy debates as dynamic networks. In J. N. Victor, A. H. Montgomery, \& M. N. Lubell (Eds.), The Oxford handbook of political networks (pp. 301-325). Oxford: Oxford University Press.

Leifeld, P. (2019). Brückenschlag in der politikwissenschaftlichen Forschung durch Diskursnetzwerkanalyse [Bridging the gap in political research with discourse network analysis]. In R. Nägler (Ed.), Steuermannskunst im Hochschulmanagement: Die Wirkungskraft von Ideen und Diskursen auf die Universität [Helmsmanship in higher education manage- ment: The effects of ideas and discourses on universities] (pp. XV-XVIII). Wiesbaden: Springer VS.

Leifeld, P., \& Brandenberger, L. (2019). Endogenous coalition formation in policy debates. arXiv. Retrieved from https://arxiv.org/abs/1904.05327

Leifeld, P., \& Haunss, S. (2012). Political discourse networks and the conflict over software patents in Europe. European Journal of Political Research, 51(3), 382-409.

Leifeld, P., \& Schneider, V. (2012). Information exchange in policy networks. American Journal of Political Science, 56(3), 731-744.

Nägler, R. (2019). Steuermannskunst im Hochschulmanagement: Die Wirkungskraft von Ideen und Diskursen auf die Universität [Helmsmanship in higher education management: The effects of ideas and discourses on universities] (pp. XV-XVIII). Wiesbaden: Springer VS.

Rinscheid, A. (2020). Business power in noisy politics: An exploration based on discourse network analysis and survey data. Politics and Governance, 8(2), 286-297.

Sabatier, P. A., \& Jenkins-Smith, H. C. (1993). Policy change and learning: An advocacy coalition approach. Boulder, CO: Westview Press.

Schaub, S., \& Metz, F. (2020). Comparing discourse and policy network approaches: Evidence from water policy on micropollutants. Politics and Governance, 8(2), 184-199.

Schlager, E. (1995). Policy making and collective action: Defining coalitions within the advocacy coalition framework. Policy Sciences, 28(3), 243-270.

Wallaschek, S., Starke, C., \& Brüning, C. (2020). Solidarity in the public sphere: A discourse network analysis of German newspapers (2008-2017). Politics and Governance, 8(2), 257-271.

Weible, C. M., \& Sabatier, P. A. (Eds.). (2017). Theories of the policy process (4th ed.). New York, NY: Routledge.

\section{About the Author}

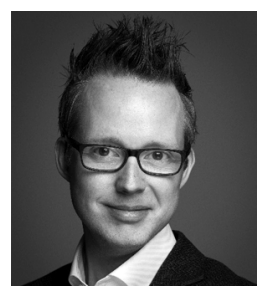

Philip Leifeld is a Professor of comparative politics in the Department of Government at the University of Essex. He was previously Professor of research methods at the University of Glasgow. His research focusses on policy analysis, comparative politics, political methodology, and network science. Philip Leifeld is the Author of several software packages, including Discourse Network Analyzer, rDNA, btergm, and texreg, and has published in the American Journal of Political Science, Journal of Politics, Physica A: Statistical Mechanics, and other journals. 